\title{
Produced Nanofibers and Technological Possibilities of LABORATORY APPARATUS 4SPIN ${ }^{\circledR}$
}

\author{
Marek Pokorny ${ }^{1}$; Jiri Rebicek; Jindrich Novak; Adela Kotzianova; Jan Klemes; Jana \\ Ruzickova; Vladimir Velebny \\ Contipro Biotech s.r.o., R\&D Department, 56102 Dolni Dobrouc, Czech Republic \\ e-mail: ${ }^{1}$ marek.pokorny@ contipro.com
}

\begin{abstract}
The 4SPIN ${ }^{\circledR}$ desktop laboratory device has been developed for the deposition of nanomaterials dedicated not only to medical applications, but also to other fields such as nanoelectronics, optics, filtration, etc. The apparatus integrates various methods to enable the preparation of nanostructured materials according to researching demands. Nine principally different emitters (most of them are usable in the method called electroblowing) and six different collectors enable researchers to perform various types of experiments. This allowed nanofibrous materials with different microscopic and macroscopic structures to be successfully prepared. The 4SPIN ${ }^{\circledR}$ laboratory device was developed at Contipro Biotech Ltd. and seven principles used were patented. The device has been certified for electrical safety by the CE mark and has been marketed since January 2013.
\end{abstract}

\section{Introduction}

Today, electrospinning equipment and technological solutions as well as electrospun materials are moving towards commercialization. Hence, there is a higher demand for laboratory and production devices. Laboratory equipment must meet the following requirements: i) multifunctional setup (all-in-one device), ii) compactness (limited lab space), iii) accuracy and reproducibility of the material produced, iv) safe and easy handling, and v) affordable price for academia [1]. The 4 SPIN $^{\circledR}$ device offers several benefits that differentiate it from devices offered by competition. It is possible to repeatedly produce nanomaterials with identical properties by implementing precisely regulated process parameters. Its central system simplifies control and also improves productivity and operator safety. Almost twenty different solutions (including hyaluronic acid and its derivatives), their blends and composites have been processed so far. Generally it can be used for the electrospinning, electrospraying and electroblowing methods [2].

\section{Research Objectives}

In this article we provide a report on the development of the design of a brand new device with a transparent cylindrical deposition chamber and a control panel (see Fig. 1). The shape of the deposition chamber has been designed for optimal formation of the desired electrostatic field, user-friendly observation of the process, easy accessory installation, and easy access and cleanability of the interior. The materials used have the necessary chemical resistance to solvent systems applied in solution preparation. The central control with a distributed network of peripherals has been chosen specially for this device to meet the requirements concerning control quality, repeatability and operational safety. The user interface features a touch screen with graphical environment designed to simplify and improve the efficiency of operation and for production process automation. Several safety elements have been integrated into the 
device to ensure user safety and to minimize the risk of injury by the electric current from low- and high-voltage wiring.

\subsection{Materials}

The functionality of the device was verified by spinning a wide range of natural and synthetic polymers. Only the most important ones are listed: hyaluronic acid (HA) and its derivatives, gelatin, collagen, chitosan, polyacrylonitrile (PAN), polyvinylalcohol (PVA), polyamide (PA 6 and 66), polyethylene oxide (PEO), polycaprolactone (PCL), polyurethane (PU), poly (Llactic acid) (PLLA), polyvinylpyrrolidone (PVP), and also inorganic glass. The polymers are dissolved into a solution in the required concentration by using any of the following solvents: distilled water, acetic acid, chloroform, ethanol, isopropyl alcohol, dimethylformamide or tetrahydrofuran.

\subsection{Methods}

Nanofibrous materials were first prepared on the 4SPIN® ${ }^{\circledR} 4 \mathrm{~S}$ LAB1 device (see Fig. 1), then analyzed on a scanning electron microscope (ZEISS Ultra) and an in-house developed confocal Raman spectroscope. All values of the process parameters were recorded and viewed in real time on a PC screen. Device settings were saved and recalled before subsequent depositions.

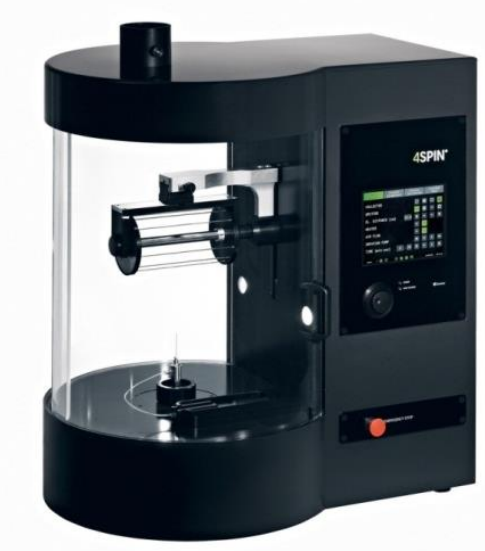

Source: Original photography taken by Contipro

Fig. 1: Laboratory device 4SPIN® C4S LAB1

We have proven the ability of the device to repeatedly produce nanomaterials with identical properties by using repetitive production. The study was carried out in a few steps in order to obtain the necessary data for evaluation: a) consistent microscopic properties during the deposition by measuring average fibre diameters, b) throughput uniformity by the weight of all samples, and c) homogeneity of layers by two processes from the perspective of the distribution of local weights and chemical composition.

\section{$2 \quad$ Results and Discussion}

Precisely-aligned nanofibers with anisotropic properties have been collected by advanced electrospinning, e.g. on static patterned and rotated collectors. Small spherical structures have been prepared using the electrospraying mode. Morphological properties were well controlled by the electroblowing process parameters. For example, a reduction of the fibre diameter down to $50 \%$ was achieved. 
Detailed studies focusing on the stability of the process were carried out using a solution with optimal parameters. Fourteen nanofibrous samples made of a 6\% HA/PEO (80:20) solution dissolved in distilled water were prepared under the same conditions. The average fiber diameter of all samples is $(154 \pm 58) \mathrm{nm}$. The average weight is $(81 \pm 7) \mathrm{mg}$. Their homogeneity determined on the basis of local weight is less than $10 \%$. The homogeneity of the two components in the final product is about $2 \%$. The presented results illustrate the preparation of nanofibrous layers with almost identical properties.

\section{Conclusions}

The most important features and capabilities of the new 4 SPIN $^{\circledR}$ technologies are presented in this work. The results show the advantages and benefits of using our laboratory equipment.

Automatic regulation of all process parameters makes it possible to achieve constant material properties in the fabrication of nanofibers. Therefore the fibre diameter does not change throughout the sample volume. Reproducible materials, i.e. products with identical properties, can be prepared by applying a precise regulation of process parameters (individual procedures can be saved and used again at any time). Various fibrous and spherical forms with macroscopic arrangement can be easily produced.

Due to its experimental versatility, safety components, easy handling, intuitive device control and other benefits the 4 SPIN $^{\circledR}$ apparatus significantly contributes to research progress in the nanofibre application field.

Although the device is intended and highly suitable for laboratory experiments, the newly developed needle-free emitter E5 is able to achieve high throughput. The results of this new patented technology will be used to upgrade the equipment, which will result in a considerably easier and cheaper transition from the development of new products to their production.

\section{Literature}

[1] PERSANO, Luana; CAMPOSEO, Andrea; TEKMEN, Cagri and PISIGNANO, Dario: Industrial Upscaling of Electrospinning and Applications of Polymer Nanofibers: A Review. Macromolecular Materials and Engineering. 2013, Vol. 298, Issue 5, 504-520. DOI: $\underline{10.1002 / \text { mame.201200290 }}$

[2] FILATOV, Y.; BUDYKA, A. and KIRICHENKO, V.: Electrospinning of micro-and nanofibers: fundamentals and applications in separation and filtration processes. New York: Begell House, c2007, xxiii, 404 p. ISBN 978-156-7002-416.

Ing. Marek Pokorny, Ph.D.; Mgr. Jiri Rebicek; Ing. Jindrich Novak; Ing. Adela Kotzianova; Mgr. Jan Klemes; Ing. Jana Ruzickova, Ph.D.; doc. RNDr. Vladimír Velebny, CSc. 


\section{VÝROBA NANOVLÁKEN A TECHNOLOGICKÉ MOŽNOSTI LABORATORNÍHO PŘÍSTROJE $4 \mathrm{SPIN}^{\circledR}$}

$4 \mathrm{SPIN}^{\circledR}$ je stolní laboratorní zařízení, které bylo vyvinuto pro depozici nanomateriálů pro lékařské aplikace, ale také pro další oblasti, jako jsou nanotechnologie, optika, filtrace a tak dále. Zařízení integruje různé metody pro umožnění př́pravy nanostrukturovaných materiálů podle výzkumných požadavků. Devět zásadně odlišných emitorů (většina z nich je použitelná v metodě zvané ,electroblowing“") a šest různých kolektorů dovoluje provádět různé druhy experimentů. Toto umožňuje př́pravu nanovlákenných materiálů s různými mikroskopickými a makroskopickými strukturami. Laboratorní přístroj $4 \mathrm{SPIN}^{\circledR}$ byl vyvinut ve firmě Contipro Biotech s.r.o. a sedm použitých principů bylo patentováno. Zařízení získalo bezpečnostní certifikát podle norem CE a bylo uvedeno na trh od ledna 2013.

\section{DiE HeRSTELLUNG VON NANOFASERN UND TECHNOLOGISCHE MÖGLICHKEITEN DES LABORGERÄTES 4SPIN ${ }^{\circledR}$}

Das 4SPIN ${ }^{\circledR}$ Desktop Laborgerät wurde für die Ablagerung von Nanomaterialien für medizinische und andere Anwendungen z.B. im Bereich der Nanoelektronik, Optik oder Filtration entwickelt. Das Gerät integriert verschiedene Methoden, um die Herstellung von nanostrukturierten Materialien den Anforderungen der Forscher entsprechend zu ermöglichen. Neun prinzipiell verschiedene Emitter (die meisten von ihnen können bei dem „Electroblowing“ genannten Verfahren verwendet werden) und sechs verschiedene Sammler ermöglichen die Durchführung von verschiedenen Versuchstypen. So können Nanofasermaterialien mit verschiedenen mikroskopischen und makroskopischen Strukturen erfolgreich hergestellt werden. Das 4 SPIN $^{\circledR}$ Laborgerät wurde von Contipro Biotech $\mathrm{GmbH}$ entwickelt und sieben verwendete Grundsätze wurden patentiert. Das Gerät ist mit der CEKennzeichnung zertifiziert und es ist seit Januar 2013 auf dem Markt.

\section{PRODUKCJA NANOWŁÓKIEN A TECHNOLOGICZNE MOŻLIWOŚCI LABORATORYJNEGO URZĄDZENIA 4SPIN ${ }^{\circledR}$}

$4 \mathrm{SPIN}^{\circledR}$ to stołowe urządzenie laboratoryjne, opracowane do celów depozycji nanomateriałów do zastosowań medycznych, jak również innych dziedzin takich jak nanotechnologie, optyka, filtracja itd. Urządzenie łączy różne metody umożliwiające przygotowanie materiałów $\mathrm{z}$ nanostrukturą zgodnie $\mathrm{z}$ wymogami prowadzonych badań. Przeprowadzanie różnych rodzajów eksperymentów możliwe jest dzięki zastosowaniu dziewięciu wyraźnie odmiennych emitorów (większość z nich może być wykorzystana w metodzie o nazwie „electroblowing“) oraz sześciu różnych kolektorów. Umożliwia to przygotowanie materiałów z nanowłókien o różnej strukturze mikroskopijnej i makroskopijnej. Laboratoryjne urządzenie $4 \mathrm{SPIN}^{\circledR}$ opracowano w firmie Contipro Biotech s.r.o., przy czym siedem zastosowanych zasad opatentowano. Urządzenie zdobyło certyfikat bezpieczeństwa wg norm CE i zostało wprowadzone na rynek w styczniu 2013 roku. 